\title{
St. Lawrence Seaway: Western Great Lakes Basin
}

\author{
Kenneth R. Olson'1, Gerald A. Miller² \\ ${ }^{1}$ College of Agricultural, Consumer, and Environmental Sciences, University of Illinois, Urbana, Illinois, USA \\ ${ }^{2}$ College of Agriculture and Life Sciences at Iowa State University, Ames, Iowa, USA \\ Email: krolson@illinois.edu
}

How to cite this paper: Olson, K.R. and Miller, G.A. (2020) St. Lawrence Seaway: Western Great Lakes Basin. Journal of Water Resource and Protection, 12, 637-656. https://doi.org/10.4236/jwarp.2020.128039

Received: June 27, 2020

Accepted: July 28, 2020

Published: July 31, 2020

Copyright (c) 2020 by author(s) and Scientific Research Publishing Inc. This work is licensed under the Creative Commons Attribution International License (CC BY 4.0).

http://creativecommons.org/licenses/by/4.0/

\section{Abstract}

The St. Lawrence Seaway connects Lake Superior, Lake Huron, Lake Michigan, Lake Erie and Lake Ontario to the Atlantic Ocean. The lakes and connecting rivers, St. Mary's, St. Claire, Detroit, Niagara and St. Lawrence, have been a major artery for transportation, migration and trade. The Menominee River flows into Green Bay and Lake Michigan and connects to the St. Lawrence Seaway. The Great Lakes have been sailed for trading and commercial purposes since at least the $17^{\text {th }}$ century. Approximately 6000 ships have sunk killing more than 30,000 sailors and passengers. Cold Canadian winds over the three Western Great Lakes pick up moisture when the lakes are not yet frozen and create snow belts in the states of Wisconsin, Michigan and in Ontario, Canada. The Western Great Lakes moderate the seasonal temperatures as they absorb heat and cool the air in the summer. The lakes radiate heat in the fall. This temperature buffering creates fruit belts further north of where the fruit is traditionally grown. During the 1950s and 1960s all of the Agent Blue, the arsenic containing herbicide used in Vietnam War, was manufactured on the banks of the Menominee River by the Ansul Company at Marinette, Wisconsin. The groundwater and the river bottom are now heavily contaminated with arsenic compounds that were released from 1957 to 1977 by Ansul as a result of the manufacture of the herbicide. The linkage of Lake Michigan to the Mississippi River has allowed Chicago's wastewater to be disposed of into the tributaries of the Illinois River and Mississippi River to avoid contaminating Lake Michigan the source of Chicago's drinking water. An unintended consequence of linking the Western Great Lakes basin with the Mississippi River basin was the creation of the wet pathway (Chicago Sanitary and Ship Canal) through which the flying Asian carp is trying to use to get into the Great Lakes. An electric fish barrier was constructed on the Chicago Sanitary and Ship Canal in an attempt to prevent the carp from migrating into Lake Michigan, the Great Lakes basin and the St. Lawrence Seaway. 
The Western Great Lakes shorelines are actively eroding partly as a consequence of the high surface water levels. In June of 2020 Lake Michigan, Lake St. Claire and Lake Huron experienced the highest water level ever recorded since the 1800s. The high risk erosion areas are retreating at the average rate of $30 \mathrm{~cm}$ per year for the last 15 years. Planned urban development in a high risk area helps to prevent the loss of buildings. Locating structures back from lake bluffs promotes natural shorelines and reduces the need for engineered shore protection. Erosion of the sediment under the Mackinac Bridge and pipeline has occurred. The pipeline which carries 87 million liters of oil per day between Sarnia, Ontario and Superior, Wisconsin is at risk.

\section{Keywords}

Agent Blue, Ansul Company, Asian Carp, Arsenic, Marinette, Wisconsin, Menominee River, Navigation, Sediments, Shipwrecks, Shore Erosion

\section{Introduction}

The Western Great Lakes Basin consists of Lake Huron, Lake Michigan, Lake Superior and many secondary lakes and their surrounding lands in the states of Illinois, Michigan, Indiana, Wisconsin and Minnesota in the United States, and the Canadian province of Ontario. Each individual Great Lake watershed has sub-basins (Figure 1). The Great Lakes are interconnected by the St. Lawrence Seaway [1], a sequence of rivers, lakes, straits and canals that flow naturally to

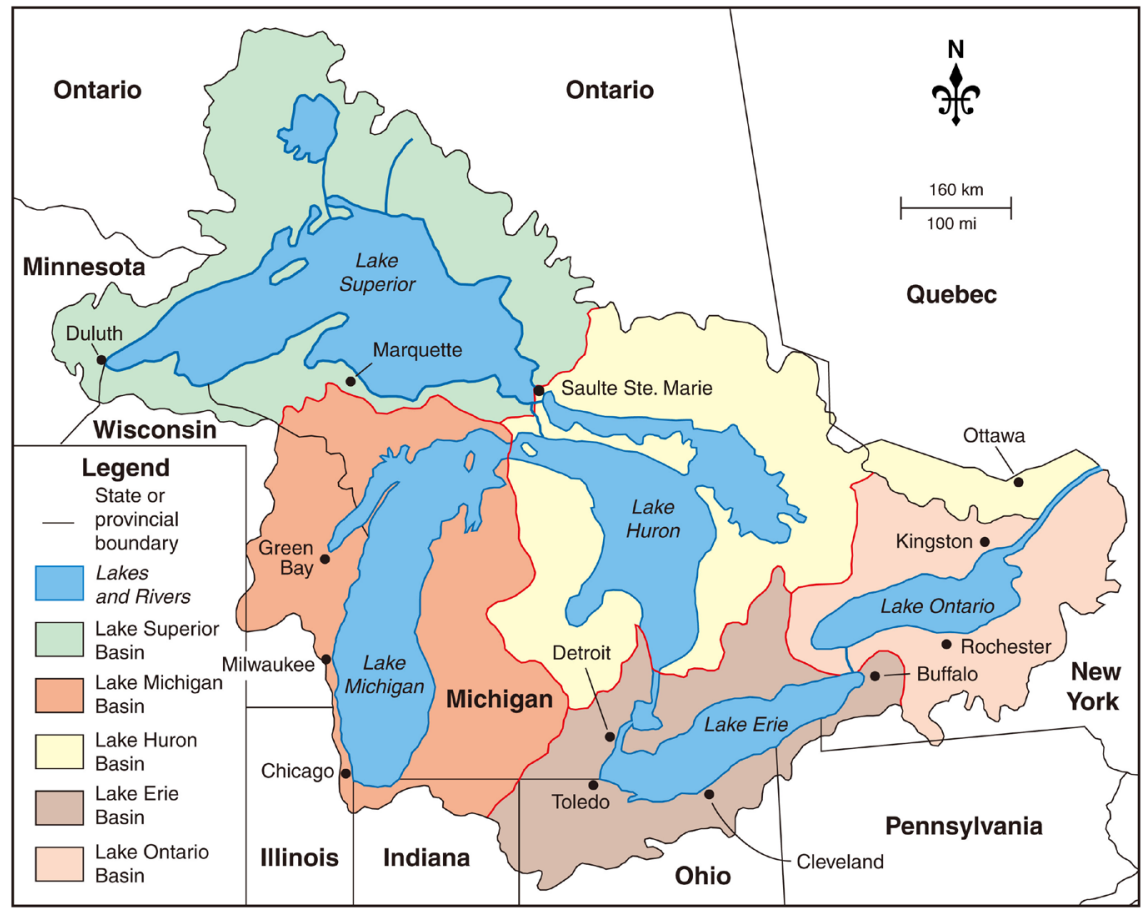

Figure 1. Great Lakes Basin and individual lake sub-basin map. Map by Mic Greenberg. 
Lake Erie, Niagara River, Lake Ontario, the Lawrence River and the Gulf of Saint Lawrence. The farthest west of the Great Lakes is Lake Superior and it has the highest elevation [2]. The Binational Great Lakes Commission monitors the Western Great Lakes basin. There are more than 15 million people living in the basin and the area includes the US cities of Duluth, Milwaukee, Chicago [3] and Marquette which are all located on the shores of the Western Great Lakes.

The primary objective of this paper is to document the environmental threats [4] [5] to the Western Great Lakes basin which has only one natural outlet, the Detroit River which flows naturally into Lake Erie. These environmental challenges which are starting to requiring mitigation including the impact millions of people living in the Western Great Lakes basin, navigation on the St. Lawrence Seaway, thousands of shipwrecks [1] [6] [7] at the bottoms of Lake Huron, Lake Superior and Lake Michigan, disposal of treated and untreated industrial and urban waste into the lakes, pollution of the sources of drinking water, land use change, shoreline erosion, building structures on the shoreline banks, underwater oil and gas pipelines, invasive species including Asian carp, and record high Western Great Lake water levels [8].

\section{Study Site}

\subsection{Historical Geology of the Great Lakes}

During the Precambrian (4.5 to 0.54 billion years ago) magma created the intrusive granites of the Canadian Shield (Figure 2 and Figure 3). These ancient granites can be seen on the North Shores of Lake Huron and Lake Superior (Figure 4). During the Wisconsin glaciation about 14,000 years ago, the area was covered with $2 \mathrm{~km}$ thick ice sheet]. The land contours were carved by the advance of the continental glacier. The meltwaters left gravel, sand, clay and boulders deposits

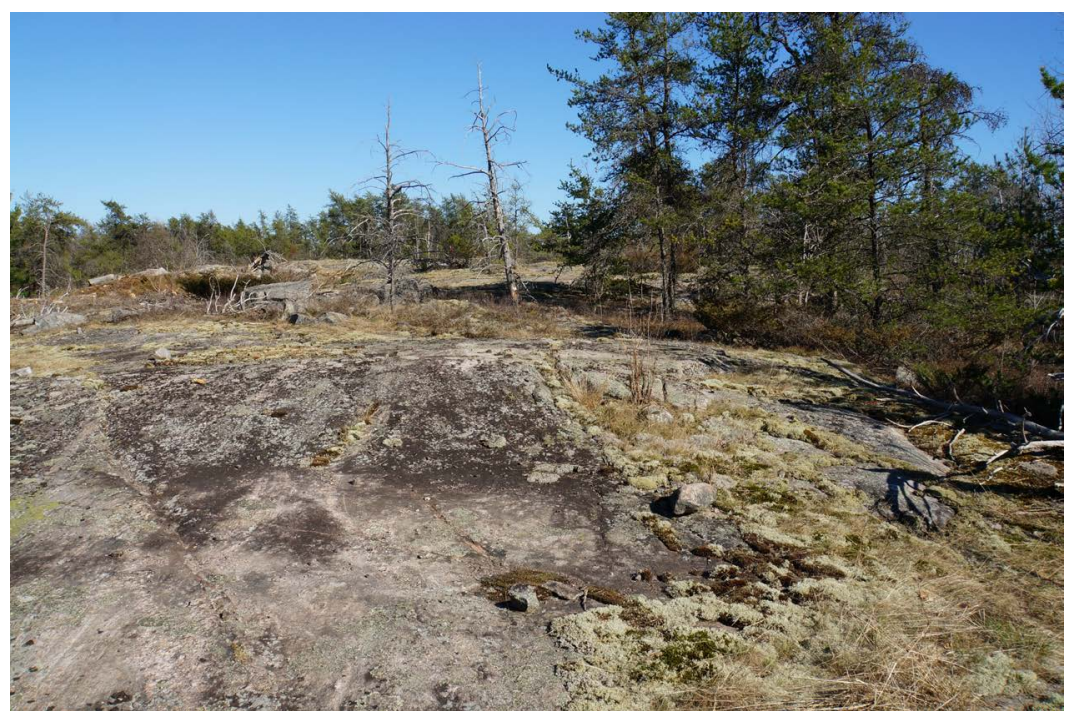

Figure 2. The Canadian shield near Sunbury, Ontario. The granite bedrock is near the surface with a thin soil. Forest is the dominant land use. Photograph by Lois Wright Morton. 


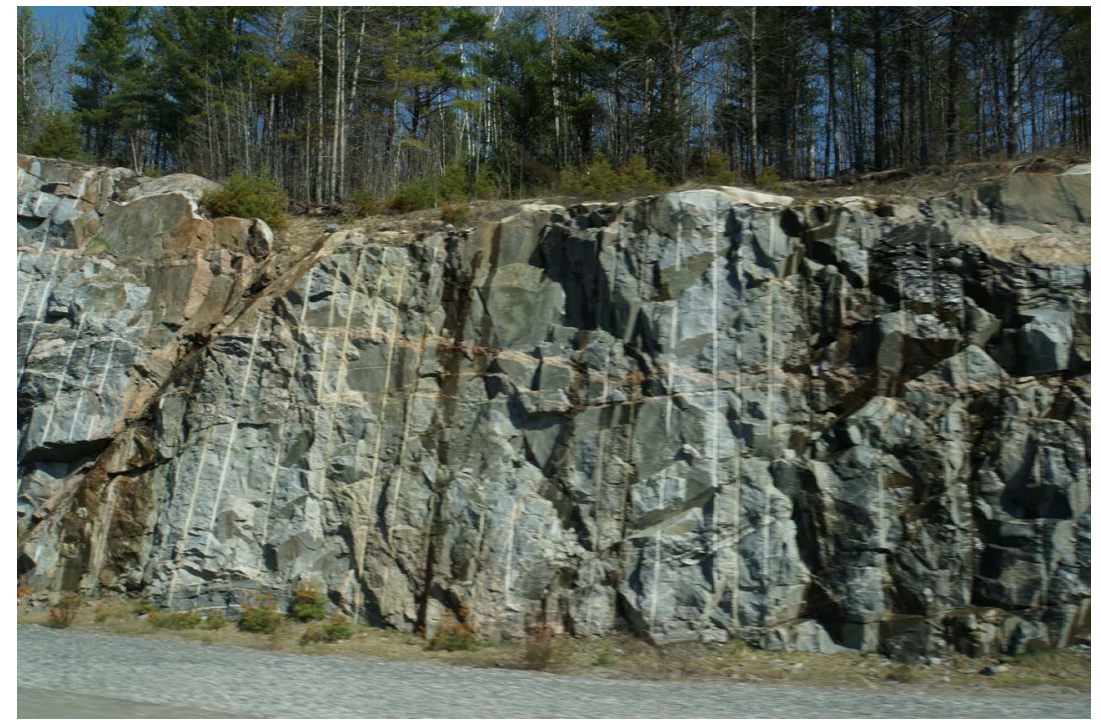

Figure 3. A highway road cut through the Canadian shield near Sunbury, Ontario.

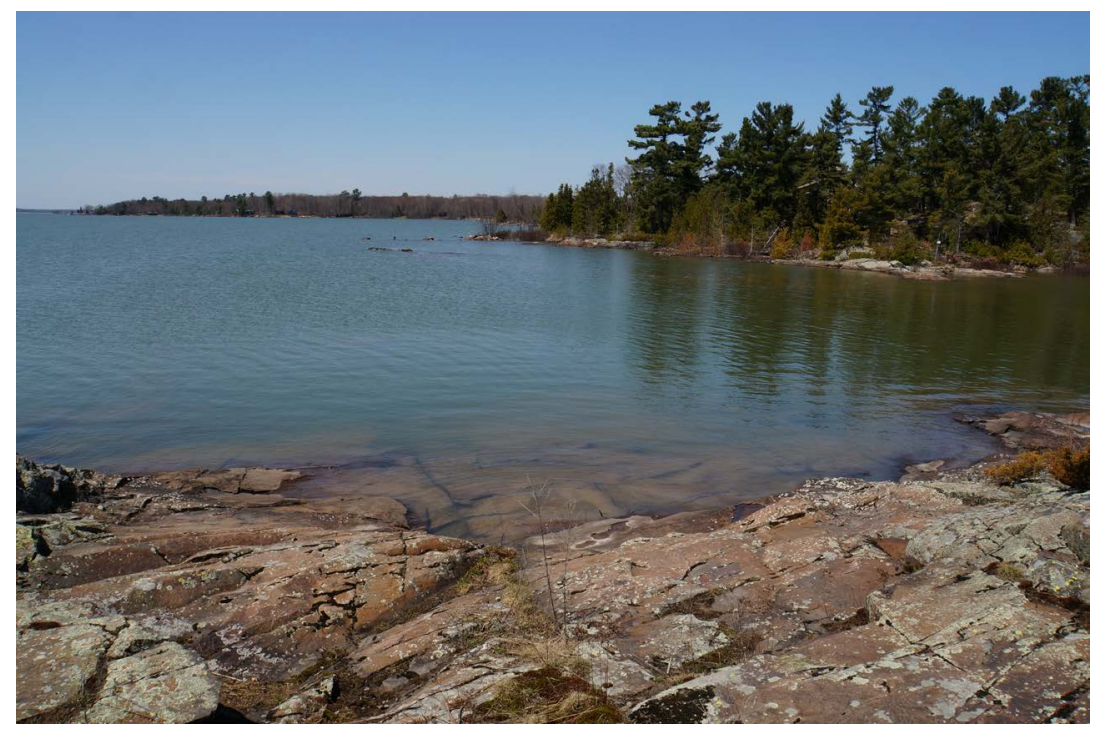

Figure 4. The shore of Lake Huron is underlain but the bedrock of the Canadian shield. Photograph by Lois Wright Morton.

on the lake plain. The Great Lakes began to form during the last glacial period by melting ice as the continental glaciers retreated north about 10,000 years ago [9].

Before the glaciation, around 2.8 million years before present (YBP), Lake Superior, Lake Michigan and Lake Huron were occupied by ancient rivers and then low-lying depressions were created by glacial ice advances. This ancient drainage system was destroyed and carved out by the first major glacier. This and subsequent glaciers deepened and enlarged the lowlands [9].

\subsection{Soils of Ontario}

The Canada Land Inventory Soil Capability Classification maps and thermal heat unit maps for Canada were used to determine prime agricultural lands 
(Classes 1, 2 and 3). Only 5\% of Canadian soils are considered prime agricultural lands. The central Ontario Zone is fortunate to contain a large portion of all the prime agricultural lands in Canada. Most are along the shores of the Western Great Lakes. Unfortunately, this is the fastest growing Canadian urban region. Settlement was most successful in suitable agricultural areas. Ontario was initially an agrarian society (Figure 5). These successful communities attracted service industries. Most of the prime agricultural land is located south of the Canadian Shield along the Lake Ontario shoreline and southwestern Ontario to the west of Lake Ontario and north of Lake Erie. This area in Canada also has the highest thermal units [10].

\subsection{St. Lawrence Seaway, Great Lakes Waterway Links}

The St. Lawrence Seaway connects Lake Superior, Lake Huron, Lake Michigan, Lake Erie, Lake Ontario, St. Lawrence River, Gulf of Saint Lawrence and to the Atlantic Ocean. Historically the St. Lawrence Seaway has handled the bulk of the shipping (Figure 6). The 5 Great Lakes form the largest group of freshwater lakes on the earth and $2^{\text {nd }}$ largest by total volume or $21 \%$ of the world's surface fresh water. The total surface is $244,106 \mathrm{~km}^{2}$ and a total volume of $22,671 \mathrm{~km}^{3}$. The Great Lakes have been considered an inland sea due to their sea-line characteristic rolling waves (Figure 7), sustained winds, strong currents (Figure 8), great depths and distant horizons). The lakes and connecting rivers including St. Mary's, St. Clair, Niagara, Detroit and St. Lawrence rivers, have been a major highway for transportation, migration and trade. The Great Lakes (Figure 1) are home to many aquatic species and the target of invasive species, such as Asian Carp, which threatens the basin's diversity The Great Lakes Basin is a single, interconnected body of fresh water with each of the 5 Great Lakes in separate basins. The Western Great Lakes water drains from Lake Superior to Lake Huron and Lake Michigan and then southward to Lake Erie [3].

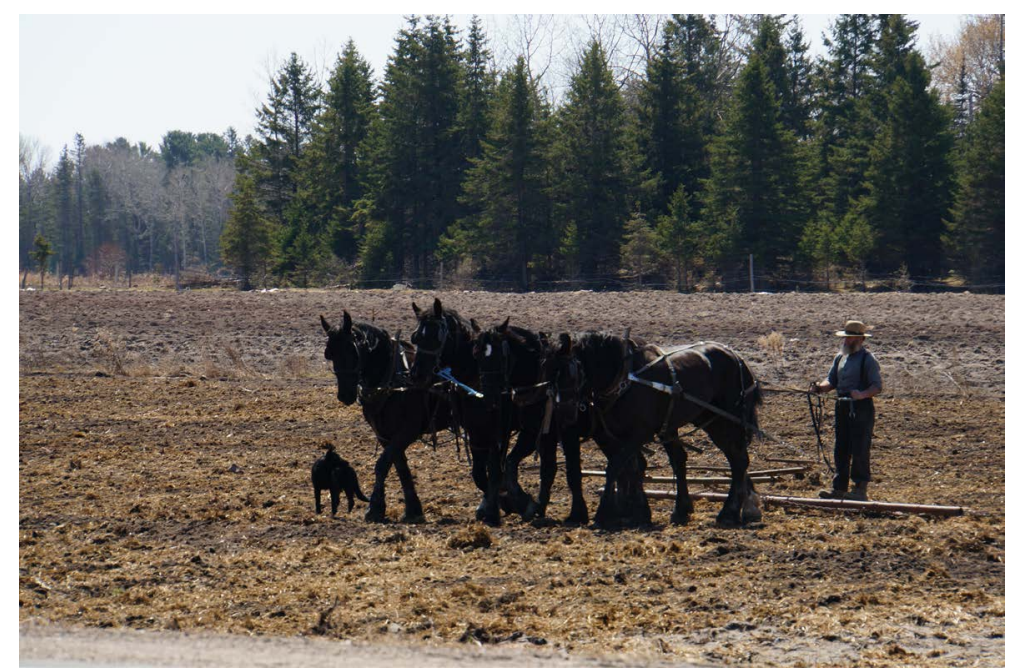

Figure 5. The farming was done by horse power. This farming method is still maintained by the Amish. Photograph by Lois Wright Morton. 


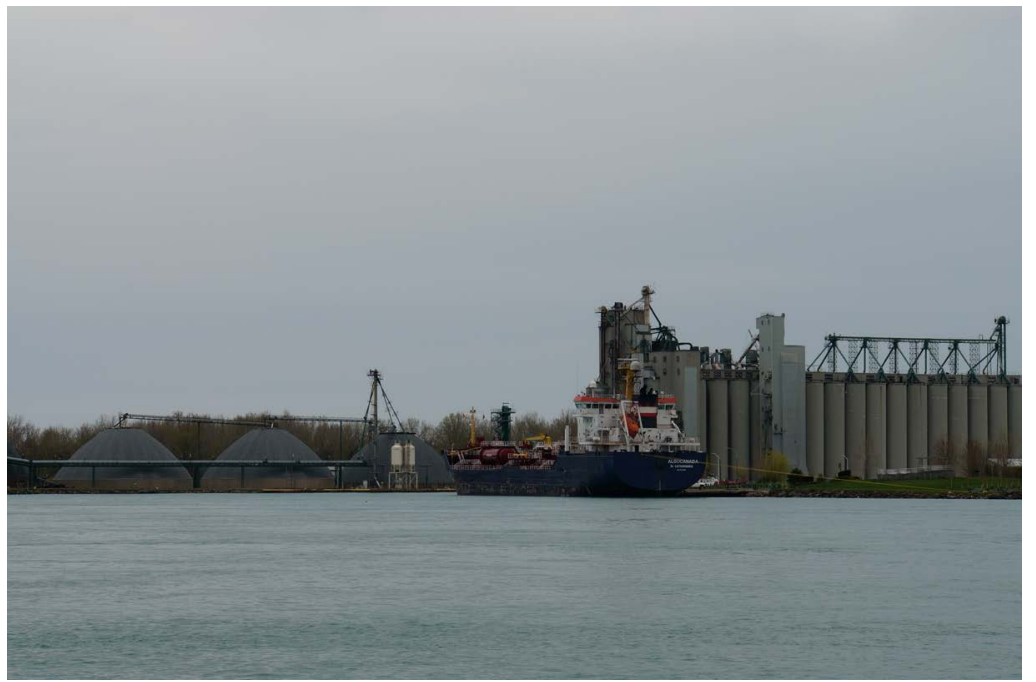

Figure 6. Ports all along the St. Lawrence Seaway are used to load grain.

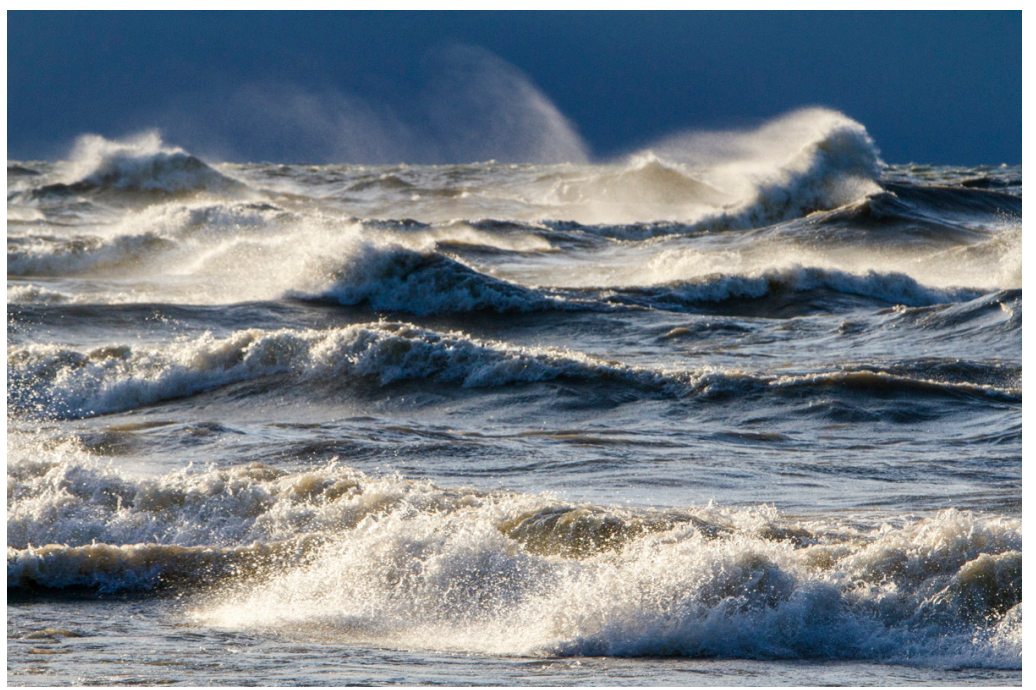

Figure 7. The waves on Lake Michigan. Photograph by Houssam Attal.

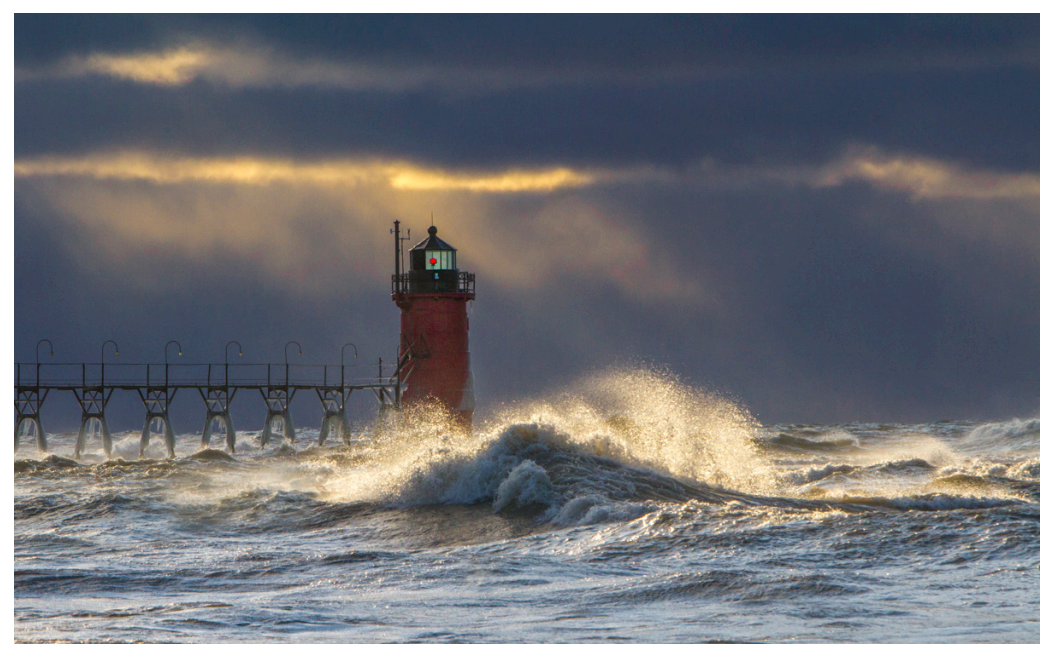

Figure 8. A South Haven light house on Lake Michigan. Photograph by Houssam Attal. 
By 1871, the St. Lawrence River locks and canals allowed the transit of vessels $57 \mathrm{~m}$ long, $13.6 \mathrm{~m}$ wide and $2.7 \mathrm{~m}$ deep to enter the Western Great Lakes basin via Lake Ontario and Lake Erie. The St. Lawrence Seaway locks were enlarged three times to an eventual size of $233 \mathrm{~m}$ long, $24 \mathrm{~m}$ wide and $9.1 \mathrm{~m}$ deep [3].

\subsection{Lake Superior}

Lake Superior has a surface area of $82,000 \mathrm{~km}^{2}$. Lake Superior drains to the southwest and into St. Mary's River and the Soo Locks at Sault Ste. Marie (Figure 9). Lake Superior is the 3rd largest lake on the earth by volume and the largest Great Lake assuming Lake Michigan and Lake Huron are measured and totaled separately. Lake Superior has an MSL elevation of $183 \mathrm{~m}$ and is the highest of all the Great Lakes. Annual storms have wave heights over $6 \mathrm{~m}$ with recorded waves over $9 \mathrm{~m}$ and have contributed to the high number of shipwrecks in Lake Superior. The Soo Locks (Figure 9) were built to enable ships to bypass the St. Mary's rapids and overcome the approximately $8 \mathrm{~m}$ height difference between Lake Superior and Lake Huron. The shoreline (Figure 10) of the lake is $4390 \mathrm{~km}$. By car, it takes $2100 \mathrm{~km}$ of driving to circle the lake. The St. Mary's River, including the Soo Locks connect Lake Superior to Lake Huron and Lake Michigan via the St. Mary's River (Figure 11).

The Canadian Shield region granites are rich in minerals. The uplands have granite bedrock exposed at the surface (Figure 2 and Figure 3 ) with shallow, low productivity soils. The dominant land uses are forestry and mining. The Tahquamenon Falls with brownish water is a result of tannic acid a product of decaying bark and plant tissue (Figure 12). Thunder Bay and Duluth, Minnesota are located on the west side of Lake Superior. These cities grew into important transportation hubs for the shipping of grain, iron ore and coal.

\subsection{Lake Huron}

Lake Huron is one of the 5 Great Lakes of North America. It is the eastern portion

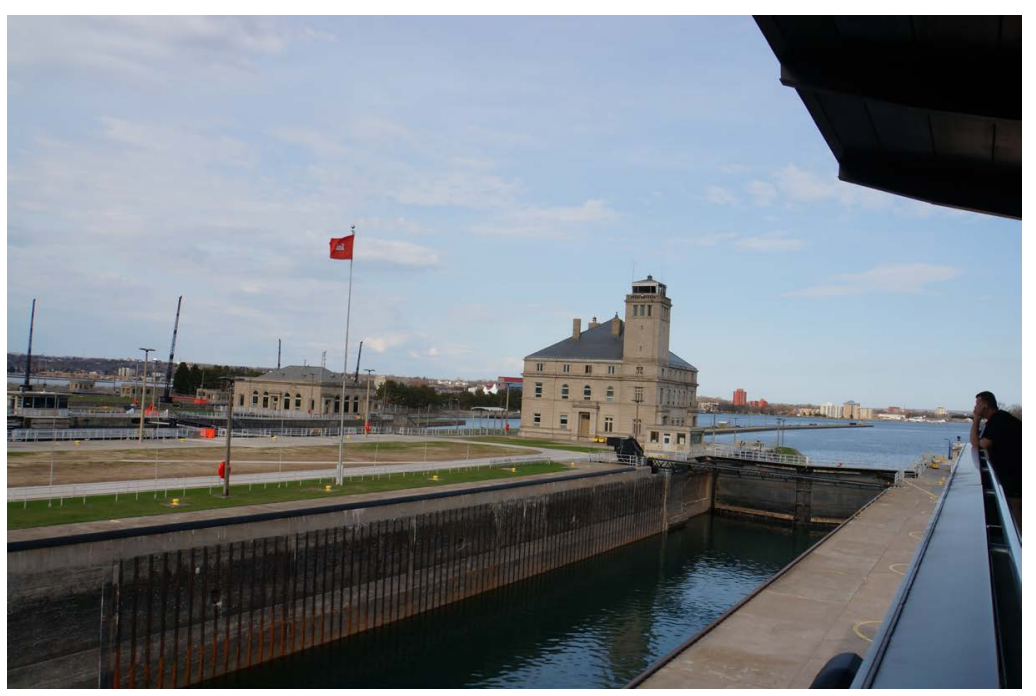

Figure 9. Soo locks on St. Mary River in Sault Ste. Marie, Canada. 


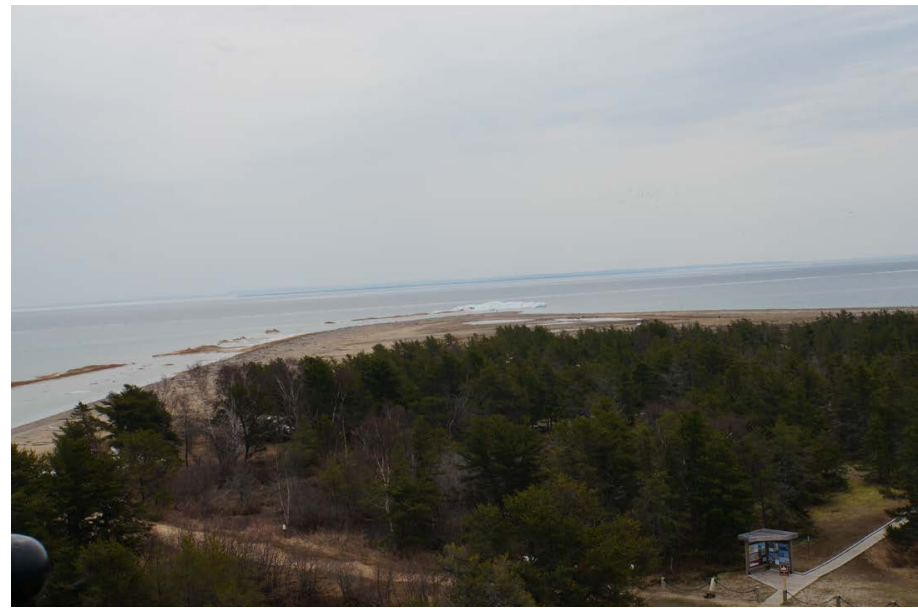

Figure 10. A view Whitefish point extending into Lake Superior from light tower at the Shipwreck Museum.

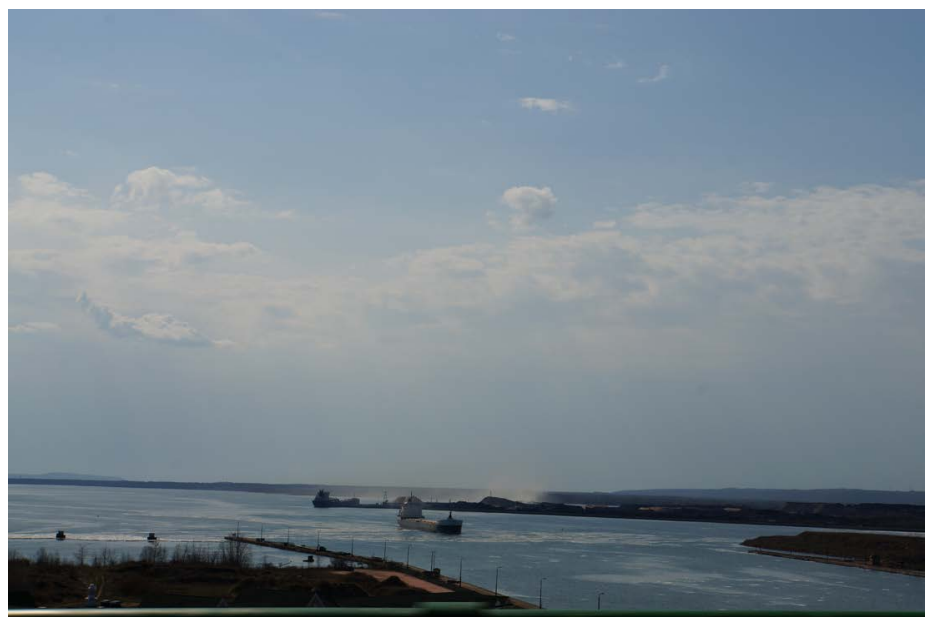

Figure 11. Ships traveling from the St. Mary River into Lake Michigan. Photograph by Lois Wright Morton.

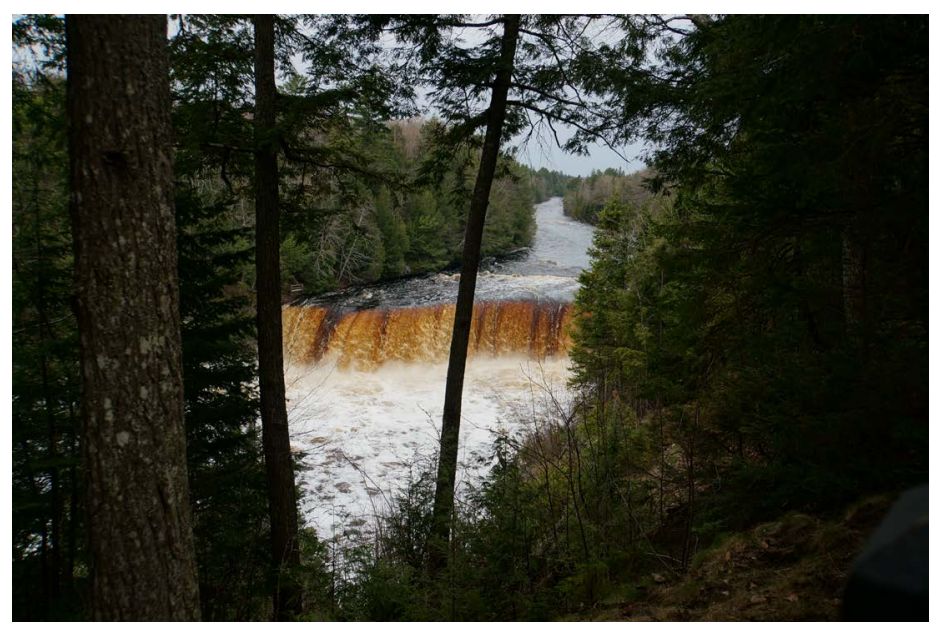

Figure 12. Tahquamenon Falls south of Lake Superior. The brownish yellow water is a result of Tannic acid from bark and other decaying plant materials. Photograph by Lois Wright Morton. 
of Lake Michigan-Huron and have the same $176 \mathrm{~m}$ elevation. They are connected by $8 \mathrm{~km}$ wide and $37 \mathrm{~m}$ deep Straits of Mackinac with the famous Mackinac Bridge (Figure 13). Technically Lake Huron and Lake Michigan are one Great Lake since they are only separated by the $8 \mathrm{~km}$ wide Straits of Mackinac (Figure 14).

The large Georgian Bay located to the east of Lake Huron adds to the size of Lake Huron. The north and east sections of Lake Huron are in Canadian province of Ontario and south and west portions of the lake are in Michigan. The main inlet is St. Mary's River near Sault Ste. Marie (Figure 11) and the main

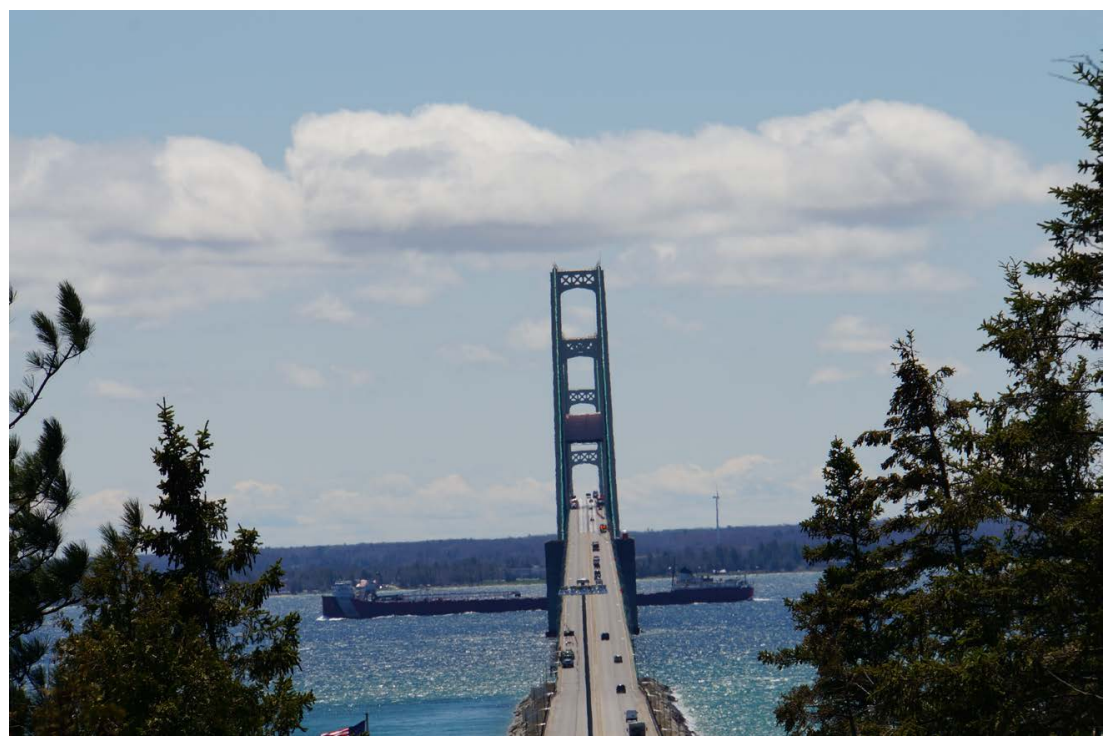

Figure 13. Mackinac Bridge over the Straits of Mackinac which separates Lake Michigan from Lake Huron. Photograph by Lois Wright Morton.

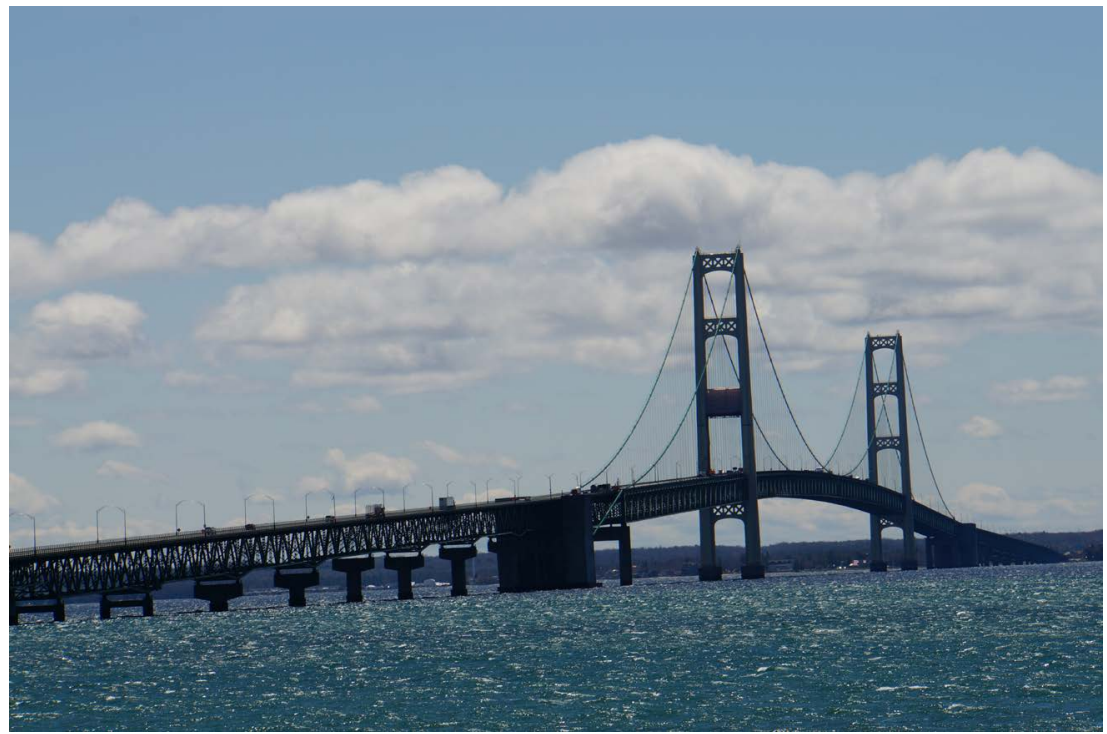

Figure 14. The Mackinac Bridge connects the upper and lower peninsulas of Michigan. An oil and gas pipeline parallels the bottom of the lake and at the base of the bridge. Photograph by Lois Wright Morton. 
outlet in St. Claire River. Lake Huron has 30,000 islands and the largest shoreline of the 5 Great Lakes counting the islands. Lake Huron is 3rd largest lake by volume $3540 \mathrm{~km}^{3}$ with an average depth $59 \mathrm{~m}$ and a $229 \mathrm{~m}$ maximum depth. Aggregate lake Huron-Michigan at $117,000 \mathrm{~km}^{2}$ would be the largest of the Great Lakes.

Lake Huron connects to Lake Michigan via the Straits of Mackinac (Figure 14). Lake Huron connects to Lake Erie via the Detroit River, St. Clair River, and Lake St. Clair (Figure 1). There are no locks on the St. Clair and Detroit rivers. The Detroit River discharge rate into Lake Erie is determined by the width of the St. Clair and Detroit rivers and the dredged channel depth.

\subsection{Lake Michigan}

Lake Michigan is the largest freshwater lake entirely within the United States. The Straits of Mackinac connect Lake Huron Michigan to Lake Michigan (hydrologically function as one). It is 2nd largest of Great Lakes by volume and 3rd based on surface area. Lake Michigan is co-joined with Lake Huron through the wide Straits of Mackinac (Figure 14) and both have the same surface elevation. Lake Michigan is shared by the states of Wisconsin, Indiana, Illinois and Michigan. Lake Michigan surface water level fluctuates monthly. The normal high-water mark is $0.6 \mathrm{~m}$ above datum which is $176 \mathrm{~m}$ (Figure 1). The highest historical level is $1.8 \mathrm{~m}$ above datum. High water records were established from February 1986 to January 1987. Historical low water occurs in winter and is 0.3 m below datum. In June of 2020 Lake Michigan and Lake Huron water levels were within $3 \mathrm{~cm}$ of the October 1986 all-time record high water mark [2] and Lake Superior was even with the January monthly high water record level [8].

The word "Michigan" is believed to come from Ojibwa word "mishigami" which means "great water". The surface area is $58,030 \mathrm{~km}^{2}$ with a volume is 4900 $\mathrm{km}^{3}$. Lake Michigan, like the other four Great Lakes, supplies millions of people in bordering basin areas with drinking water. Environmental issues still plaque the lake. Steel mills and refineries (Figure 15) operate on Lake Michigan near

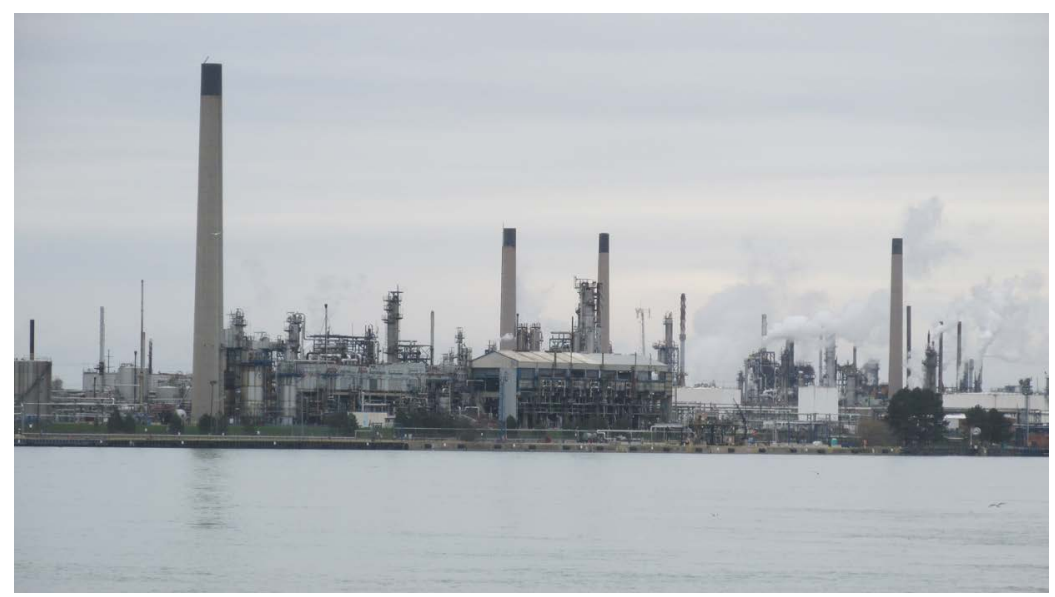

Figure 15. Industry on the St. Claire River near Detroit, Michigan. 
the Indiana shoreline and discharge into the lake. British Petroleum (BP) was a major polluter dumping thousands of kilograms of untreated sewage sludge daily from an oil refinery in Whiting, Indiana [4].

\subsection{Menominee River Flows into Green Bay and Lake Michigan}

The Menominee River flows into Lake Michigan via Green Bay. The Agent Blue, an arsenic containing herbicide, used in the Vietnam War was manufactured by the Ansul Chemical Company at Marinette, Wisconsin during the 1950s and 1960s. The contaminated surface water and sediments near Ansul manufacturing plant flow into the Menominee River. The groundwater and the river bottom sediments are heavily contaminated with arsenic which was released by Ansul Company from 1957 to 1977 resulting from the manufacture of Agent Blue. Sediment in the river contained levels as high as 11,000 ppm arsenic. From 1960 to 1966 the arsenic laden wastewater was discharged directly into the river. These discharges were a result of the accumulation of approximately 95,000 metric tons of arsenic salt that was stored on the site [5]. Ansul Company operated under two consent orders in 2009 from the U.S. Environmental Protection agency and the Wisconsin Department of Natural Resources. In September of 2009, Ansul Company agreed to spend an estimated \$28 million on mitigation activities for:

1) Removal 74,000 cubic yards of arsenic contaminated Menominee River sediments.

2) Construction a $160,000 \mathrm{~m}^{2}$ impermeable barrier to bedrock.

3) Removing $17,000 \mathrm{~m}^{2}$ of surface soils contaminated with arsenic above 16 $32 \mathrm{ppm}$.

4) To pumping and treatment of contaminated groundwater.

The Ansul remediation efforts and their total costs, in 1976-1984, was \$11 million spent to pump and treat contaminated groundwater and install a groundwater interceptor trench at the southern property border. In 1998-1999, $\$ 12.4$ million was spent to remove arsenic-contaminated sediment from the $8^{\text {th }}$ Street section of the river. An impermeable barrier system was installed to the depth of bedrock near the $8^{\text {th }}$ Street slip and adjacent salt vault. In 2012-2013, approximately $\$ 25$ million were spent to dredge and then cap river sediments. EPA orders the removal of $190,000 \mathrm{~m}^{3}$ of sediment from the main channel. Ansul (Tyco) hired a New York consulting firm, Stevenson Environmental Services, began the cleanup in July of 2012 at the cost of approximately $\$ 25$ million [4].

Ansul and other chemical companies were named as defendants in a 2005 lawsuit alleging that the use of Rainbow herbicides including Agent Orange during the Vietnam War by the U.S. military lead to birth defects in Vietnamese children. The United States District Court for the Eastern District of New York ruled that the defending companies were operating under the direct order of the Presidents of the United States (President Kennedy and President Johnson) and as such could not be sued for the consequences of the use of their Rainbow her- 
bicide product. The court ruled that the British had previously used Agent Orange during the Malayan Emergency in the 1950s and therefore had set the precedent for United States use during the American Vietnam War.

\subsection{Fishes}

Michigan is home to a wide variety of organisms including fish species and other organisms. Home to lake whitefish (Coregonus clupeaformis), lake trout (Salvelinus namaycush), yellow perch (Perca flavescens), panfish (Lepomis macrochirus), largemouth bass (Microptersrus salmoides), small mouth bass (Micropterus dolomieu), bowfin (Amia calva) and catfish (Siluriformes). Invasion of the Great Lakes by sea lampreys (Petromyzon marinus) occurred in 1919 after improvements to Welland Canal and overfishing resulted in a decline in native trout. This led to an increase of another invasive species, alewife (Alosa pseudoharengus), and predators were introduced including Salmonids (Salmonidae), brown trout (Salmo trutta), steelhead, (Oncorhynchus mykiss) coho (Oncorhynchus kisutch) and chinook salmon (Oncorhynchus tshawytscha) to control alewife [11]. The program was successful and trout and salmon exploded creating a large sport fishery.

\subsection{Energy}

Lake Michigan was used a major mode of transport for bulk goods which were moved on the Great Lakes. Coal was transported to coal fired power plants in the Western Great Lakes. Iron ore, stone and coal, all of which are used by the steel industry, are the largest categories of bulk materials shipped. Also, liquids were shipped in containers. Port of Chicago, Illinois International Port District, grain (14 million bu) and bulk liquid (800,000 barrels) facilities along Lake Calumet, Illinois are maintained by USACE [5]. There are many nuclear and coal fired power plants in the Western Great Lakes Basin. The influence of these power plants in the Western Great Lakes and the waste they produced including air pollution must be totaled to determine the environmental effect on large Western Great Lake cities such as Windsor, Chicago, Milwaukee and Marquette.

\subsection{Shipwrecks on the Great Lakes}

The Great Lakes have been sailed for trading and commercial purposes since at least the $17^{\text {th }}$ century. Approximately 6000 ships have sunk killing more than 30,000 sailors and passengers according to the staff of Great Lakes Shipwreck Museum (Figure 16) [6]. Historians [7] have estimated the number of shipwrecks is actually closer to 25,000. The Invincible was lost in 1816 and the Edmund Fitzgerald in 1975. At least 240 ships have sunk in the Whitefish Point area (Figure 10 and Figure 17). The year of record extreme was 1913. During the November storm season, two major storm fronts collided over the Great Lakes [8]. A total of 12 ships were lost and 31 were driven ashore by wind and waves. The White Hurricane (storm of 1913) claimed more than 250 lives. The 


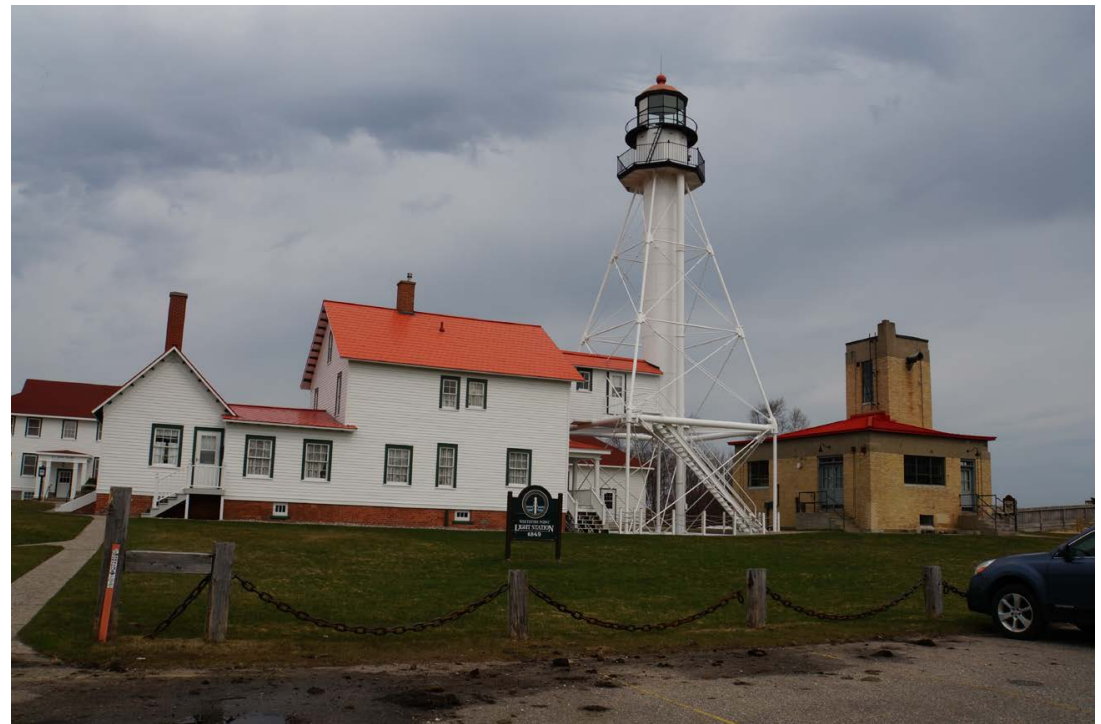

Figure 16. Whitehouse light tower and shipwreck museum. Photograph by Lois Wright Morton.

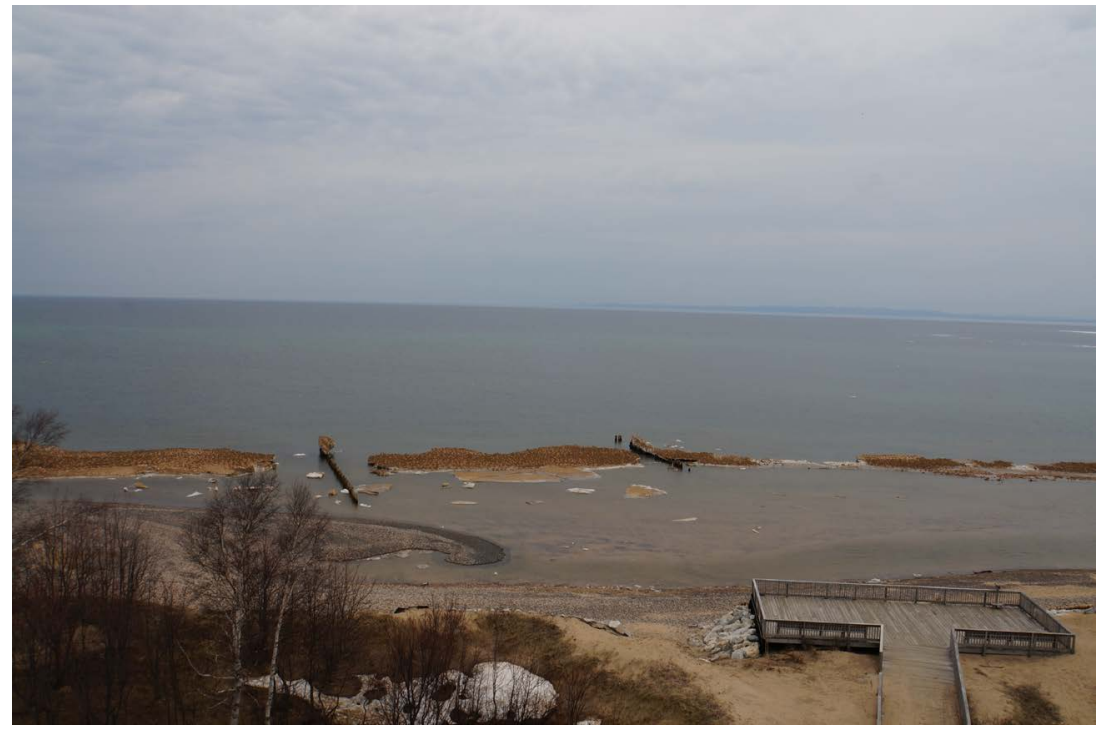

Figure 17. Sand bars and shoreline erosion near Whitehouse light tower. Photograph by Lois Wright Morton.

$90 \mathrm{mph}$ winds created $8.0 \mathrm{~m}$-high waves and a blinding snowstorm. Most of the losses during a storm occurred in Lake Huron where 8 ships sank with 200 sailors declared dead.

\subsection{Lake Effects}

The lake effect snowfalls are well-known by residents living on the shores of the Western Great Lakes. In the fall and winter, the lakes often have little or no ice cover. The prevailing winds from the west transport the moist air from the lake surface is slightly warmer than the air. As the moist air passes over the cooler land surface, the moisture produces heavy snowfalls on lands. Western Great 
Lakes snow belts are located in states of Wisconsin, Michigan, and in the province of Ontario, Canada. The Western Great Lakes moderate seasonal temperatures by absorbing heat and cooling the air in the summer. The lakes keep summer time temperatures cooler than further inland and protects against first frost during the season transitional weather. They radiate heat in the fall. Fruit belts are created further north of where the fruit is traditional grown as a consequence the temperature buffering of the lake water. For example, apples and cherry orchards and vineyards (Figure 18) can be cultivated along the northern lake shore of Lake Michigan and as far north as Nottawasaga Bay in central Ontario.

\subsection{Ecological Aspects}

The Great Lakes were historically surrounded by forest ecoregions, except for a small area of savanna or prairie adjacent to the lake shore in northeast Illinois and southeast Wisconsin and an inland area in southeastern Michigan. Logging (Figure 19), urbanization and agriculture uses have changed the land use [9]. Lake Superior's shorelines are more forested than Lake Huron. Lake Michigan has the least forested shoreline of all the Western Great Lakes.

The Great Lakes safe drinking water, rising water levels, flooding and shore erosion have been secondary concerns. The connecting the Mississippi River and the Great Lakes watersheds in 1830s by reversing the Chicago River flow are now being questioned. The original reason for linking the basins was navigation and shipping. It has been suggested that the glacial ridge (moraine) between the Great Lakes and the Mississippi River watersheds be restored to block the Asian carp from getting into Lake Michigan. However, that would require the re-reversing of local rivers and disposal of treated sewage from Chicago into Lake Michigan which is the source of Chicago's drinking water and would once again be at risk especially during storm events.

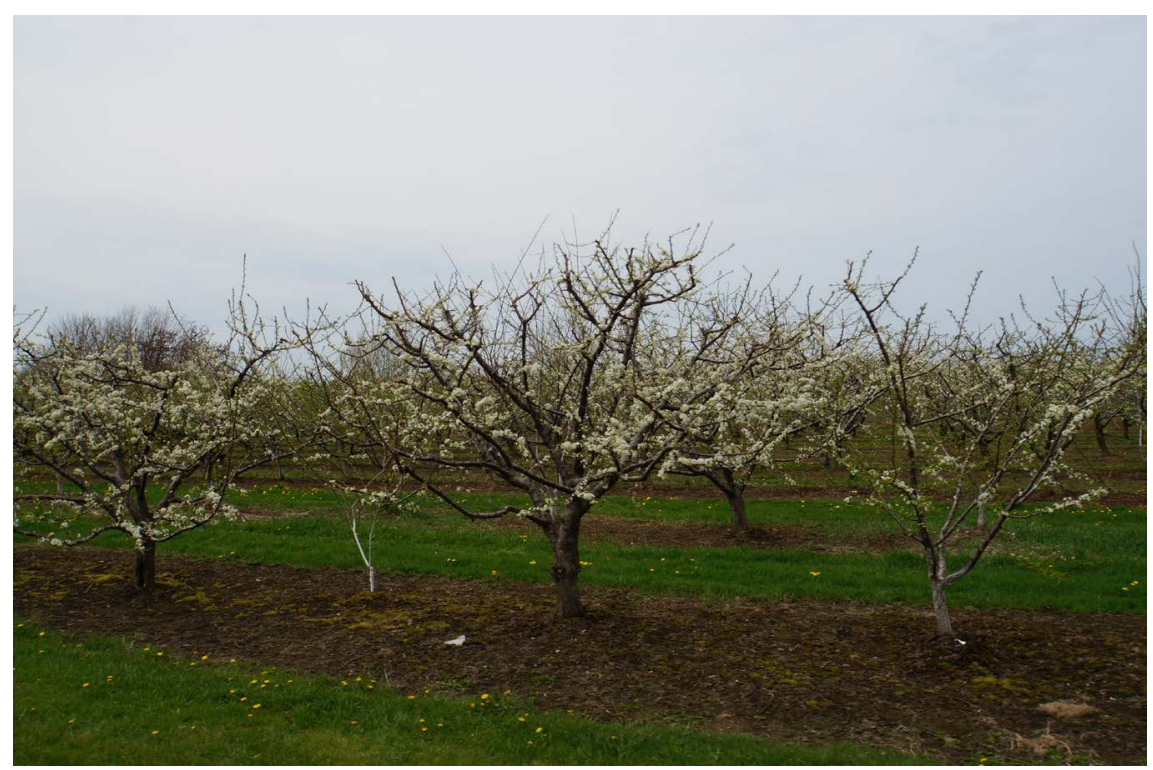

Figure 18. Flowering orchard trees along a Great Lake. 


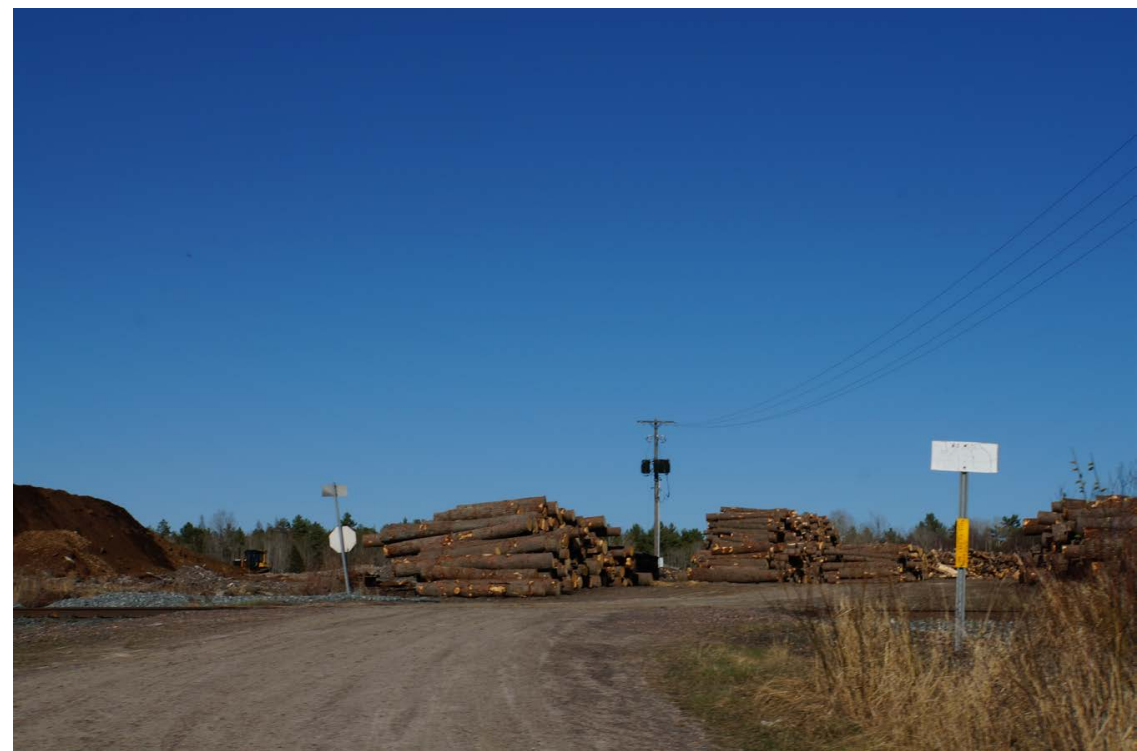

Figure 19. Logging of timber south of Sunbury, Canada.

\subsection{Great Lake Levels and Shore Erosion}

The Western Great Lakes shoreline is wearing away by the erosive forces of water and moving sand and soil from one area to another. Waves (Figure 7), water levels, rain, wind, groundwater, frost, ice thrusts (Figure 20) and people all contribute to retreating shorelines. The Western Great Lakes shorelines are actively eroding and retreating. These high risk erosion areas are retreating at an average annual rate of $30 \mathrm{~cm}$ or more per year over last 15 years. The Michigan Department of Environment, Great Lakes and Energy studies the shoreline to identify high risk areas on Lake Huron, Lake Michigan, and Lake Superior. Windblown coarse sands form dunes that dominate the eastern coast of Lake Michigan. Building to close to the edge of the bluff puts structures at risk of falling into the lake (Figure 21). Planned development in a high risk areas help to prevent the loss of structures. Locating structures safely back from the bluff may also reduce the need for engineered shore protection. Natural shorelines require less protection.

\subsection{Erosion of Sediments beneath the Pipeline}

Erosion of Straits of Mackinac sediment beneath an oil pipeline under the Mackinac Bridge has created a $24.7 \mathrm{~m}$ wide gap (Figure 14). An Enbridge Inc. oil company reported the gap in August of 2019. The Canadian company determined that the opening between the lake bottom of the Straits of Mackinac and the pipeline created no safety or integrity risk. The Enbridge's Line 5 carries 87 million liters of oil daily between Sarnia, Ontario and Superior, Wisconsin. An easement for the $4.8 \mathrm{~km}$ underwater segment at the bottom of the Straits of Mackinac was granted by the State of Michigan. The easement requires any gaps below the pipeline be less than $22.9 \mathrm{~m}$.

Environmental groups suggest the aging pipelines are likely to leak and could 


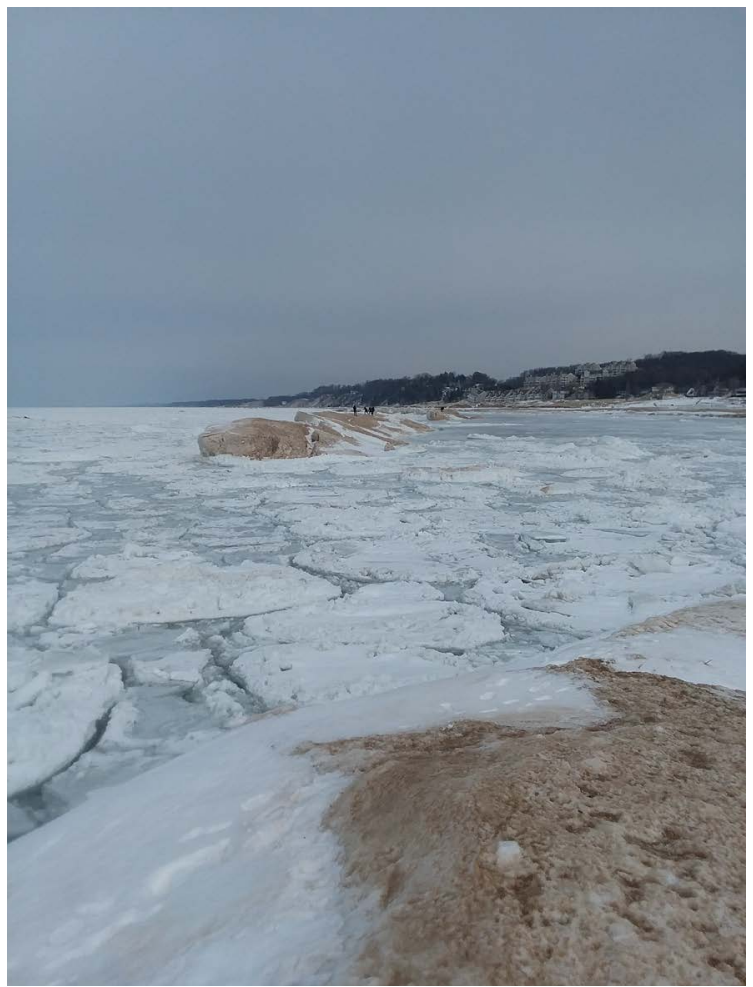

Figure 20. Lake Michigan ice thrusts eroding sand at the Holland State Park in February of 2018.

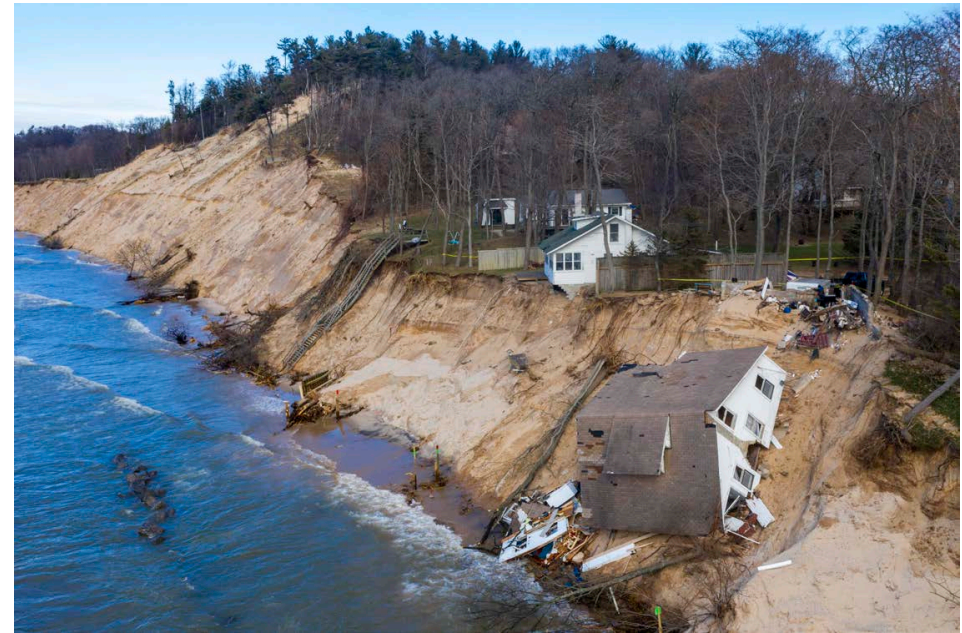

Figure 21. Lake Michigan erosion claims a beach house on January 2, 2020, in White River Township, near Montague, MI ( 2020 Mlive Media Group. All rights reserved. Used with permission.

potentially degrade hundreds of kilometers of Lake Huron and Lake Michigan shorelines and waters. In recent years Enbridge has installed 147 supports to stabilize the pipeline. Swirling currents in the Straits have washed out the bottom sediments beneath the pipeline. Enbridge has proposed 54 more anchors including one on the $24.7 \mathrm{~m}$ wide gap.

In 2018, Enbridge applied for a permit to install screw anchors to provide ad- 
ditional support. A permit was obtained from Michigan but not from USACE. Enbridge reached an agreement with the former Governor of Michigan to replace a segment of the underwater pipe and the new pipe that would be enclosed in a tunnel drilled through bedrock under the lakebed. The current Governor demanded a faster timeline which Enbridge could not meet and Michigan Attorney General filed a lawsuit in June of 2019 to shut down the pipeline under the Mackinac Bridge.

\subsection{Linkage of Great Lakes to Mississippi River}

The linkage of the Great Lakes to the Mississippi River resulted in wastewater being disposed of via the tributaries of the Illinois and Mississippi rivers to avoid contaminating Chicago areas drinking water. More than 100 years later the connected Illinois Waterway had the unintended consequence of providing a potential wet pathway for invasive organisms including fish species to get into the Great Lakes.

\subsection{Bighead and Silver Carp and the Manmade Chicago Canals}

An electric barrier was constructed in the Chicago Sanitary and Ship Canal in an attempt to prevent the carp from migrating from the Mississippi River basin into the Great Lakes basin. The silver carp (Hypophthalmichthys molitrix) (Figure 22), also known as the flying Asian carp [10], has migrated through the Mississippi River and could possibly make its way into the Great Lakes. The carp escaped the farms and began migrated up the Mississippi River system. The carp can grow to $23 \mathrm{~kg}$ or more and is noted for jumping above water. The carp were first introduced with the blessing of the EPA in the 1970s to help remove algae from catfish farms in Arkansas [10]. The carp now threaten to enter the Great Lakes through the manmade canals, including the Chicago Sanitary and Ship Canal, which connects the Great Lakes watershed to the Mississippi River watershed [1]. The carp displace native species of filter feeding fish by removing the bottom of the food chain for indigenous species. One of the most successful approaches has been to harvest the carp for food (Figure 23).

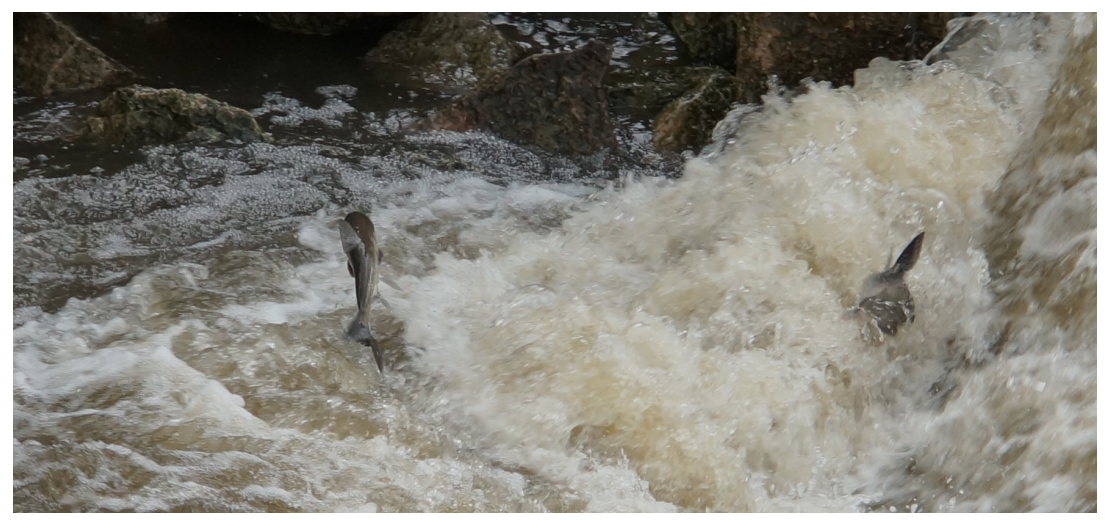

Figure 22. Silver carp trying to get through the Marseilles lock and dam on the Illinois River. 


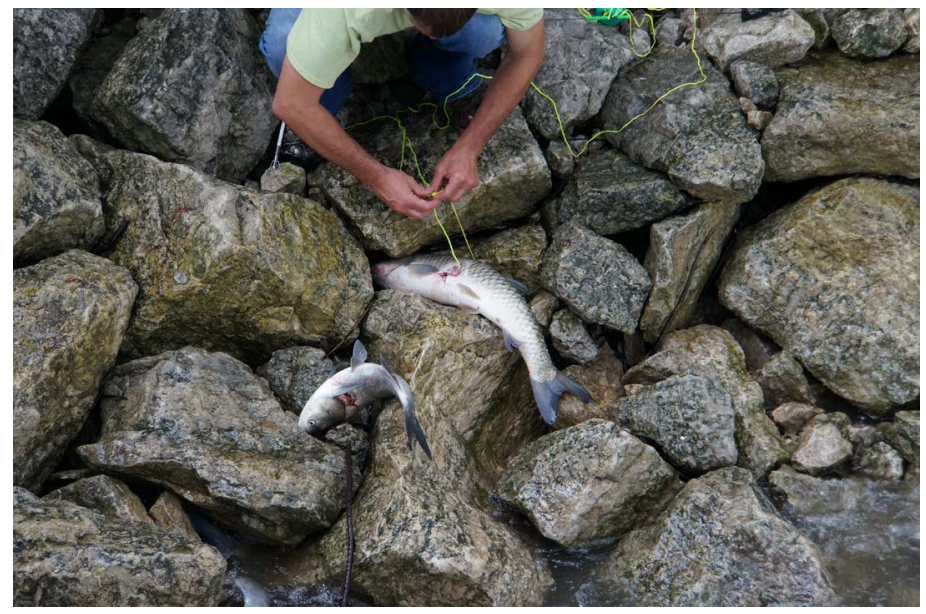

Figure 23. Silver carp being harvested by a fisherman near the Marseilles lock and dam on the Illinois River.

There are several kinds of Asian carps that have spread (or are spreading) around North America, and the two that have garnered the most attention at present are the silver carp and bighead carp (Hypophthalmichthys nobilis) (personal communication, Dr. Cory David Suski, NRES, ACES, UIUC) [1]. Most of the waterway connections only have water at certain times of the year, and the Chicago waterway is the most prominent connection (largely because it is always wet) and is the center of attention, but there are other connections. Dr. Suski suggested the carp do not displace native fishes and he is not aware of any displacement to date. Dr. Suski noted that the Asian carp out-compete the native fish for food, and several species of fishes (particularly filter feeding fishes) have experienced reduced conditions, likely through competition [1]. There are other carps (black carp, grass carp) that are less prominent, but silver and bighead are the two that are the biggest concern at present-there are actually 18 different pathways by which evasive species could pass from the Mississippi River basin into the Great Lakes basin [1].

On December 21, 2009, Michigan State Attorney General Mike Cox filed a lawsuit with the U.S. Supreme Court seeking the closure of the Chicago Sanitary and Ship Canal to keep Asian carp out of Lake Michigan. The state of Illinois and the USACE, which constructed the canal, were co-defendants in the lawsuit. The Chicago Sanitary and Ship Canal remains open with electronic fish guards in place to stop the Asian Carp from entering the Great Lakes basin via the only wet migration pathway.

\section{Summary and Conclusions}

The Western Great Lakes Basin consists of Lake Superior, Lake Michigan and Lake Huron, many secondary lakes and the surrounding lands drain directly through tributaries and into the Western Great Lakes. There are more than 15 million people living in the basin. The Western Great Lakes are interconnected by a sequence of rivers, lakes, straits and canals that drain to the Atlantic Ocean 
via Lake Erie, Niagara River, Lake Ontario, St. Lawrence River and the Gulf of Saint Lawrence. The primary objective of Canada and the United States governments was to create a navigable waterway called the St. Lawrence Seaway.

The St. Lawrence Seaway is a maze of canals, locks and channel in the US and Canada that permit ocean-going vessels to go from Atlantic Ocean to Great Lakes of North America. The lakes and connecting rivers have been a major highway for the transportation, trade and migration.

The existence of the St. Lawrence Seaway permitted the manufacture of Agent Blue, the herbicide which contained arsenic, on the Menominee River at Marinette, Wisconsin and the interior of the United States and the subsequent shipment in barrels on ocean going vessels directly to the South China Sea and the shores of South Vietnam.

The canal linkage Great Lakes via the Lake Michigan basin to the Mississippi River basin has allowed Chicago's wastewater to be disposed of into the tributaries of the Illinois River and Mississippi River to avoid contaminating Lake Michigan the source of Chicago's drinking water. An unintended consequence of linking the Western Great Lakes basin with the Mississippi River basin was the creation of the wet link (Chicago Sanitary and Ship Canal by digging through the drainage divide and reversing the Chicago River flow) through which the flying Asian carp is trying to use to get into the Great Lakes. An electric fish barrier was constructed on the Chicago Sanitary and Ship Canal in an attempt to prevent the carp from migrating into Lake Michigan, the Great Lakes basin and the St. Lawrence Seaway.

The Western Great Lakes were historically surrounded by forest ecoregions, except for a small area of savanna or prairie adjacent to the lake shore in northeast Illinois and southeast Wisconsin and an inland area in the southeastern Michigan. Logging, agricultural and urban uses have changed the land use. The Great Lakes shoreline is an actively eroding coast shoreline. Studies are needed to identify high risk areas. Building a structure too close to the edge of the bluff puts the structure at risk of falling into the lake. Planned development in a high risk area helps to prevent the future loss of buildings. Locating structures back from lake bluffs promotes natural shorelines and reduces the need for engineered shore protection.

\section{Acknowledgements}

Published with funding support from USDA, NIFA, Water Division, Department of NRES and the Director of the Illinois Office of Research, College of Agricultural, Consumer, and Environmental Science, University of Illinois, Urbana, Illinois and the Iowa Agriculture and Home Economics Experiment Station, College of Agriculture and Life Sciences at Iowa State University, Ames, Iowa.

\section{Conflicts of Interest}

The authors declare no conflicts of interest regarding the publication of this paper. 


\section{References}

[1] Joshi, R. (2019) Ten Great Lakes Shipwrecks Maritime History.

[2] United States Army Corps of Engineers (2020) Lakes Michigan-Huron Water Levels.

http://1re-wm.usace.army.mil/ForecastData/BulletinGraphics/MBOGLWL-mich_hr $\underline{\text { n.pdf }}$

[3] Olson, K.R. and Morton, L.W. (2017) Chicago's 132-Year Effort to Provide Safe Drinking Water. Journal of Soil and Water Conservation, 72, 19A-25A. https://doi.org/10.2489/jswc.72.2.19A

[4] Schmurr, R. (2017) A “Toxic Tour" of the Whiting Refinery on the Shores of Lake Michigan. Belt Magazine.

[5] Environmental Protection Agency (EPA) Staff (2017) Hazardous Waste Cleanup: Ansul Inc. Stanton St. Facility, Marinette, Wisconsin.

[6] Childs, A.A. (2011) A Michigan Museum of Shipwrecks. Smithsonian Magazine.

[7] Thompson, M.L. (2000) Graveyard of the Lakes. Wayne State University Press, Detroit.

[8] United States Army Corps of Engineers (2020) Lake Superior Water Levels. http://lre-wm.usace.army.mil/ForecastData/BulletinGraphics/MBOGLWL-superior. pdf

[9] Olson, K.R. and Morton, L.W. (2016) Managing the Mississippi and Ohio River Landscapes. Book Division, Soil and Water Conservation Society.

[10] United States Department of Agriculture, Natural Resources Conservation Service (2006) Land Resource Regions and Major Land Resource Areas of the United States, the Caribbean, and the Pacific Basin. U.S. Department of Agriculture Handbook, p. 296.

[11] Miller, R.R. (1957) Origin and Dispersal of the Alewife in the Great Lakes. Transactions of the American Fisheries Society, 86, 97-111. https://doi.org/10.1577/1548-8659(1956)86[97:OADOTA]2.0.CO;2 